\title{
Stability Analysis of Aifa Bridge Abutment in Fafurwar District, Bintuni Bay Regency, West Papua Province
}

\author{
Muhammad Yunus ${ }^{\mathrm{a}, *}$, Zharin Fahra Syahdinar ${ }^{\mathrm{b}}$ \\ aDepartment of Civil Engineering, Polytechnic State of Fakfak. Email: muhammadyunus@ polinef.id \\ bepartment of Civil Engineering, Polytechnic State of Fakfak. Email: zharinfsyahdinar@gmail.com
}

\begin{abstract}
In the construction of public infrastructures, especially road infrastructure, bridge construction work plays a very important role besides the construction of the road itself. One of the matters that deserves the attention of the planners in designing a bridge structure is the design of the substructure, this is because the substructure determines the quality and service life of a bridge. Besides, at present many cases of bridge structure failures are caused by failures of the substructure in holding the load acting on the bridge. This study aimed to determine the stability of the abutment to sliding failure and the stability of the abutment to overturning failure on the construction of the Aifa bridge in the Bintuni Bay Regency. From the results of the calculation of the stability of the abutments to sliding failure, when the abutments were in normal conditions, the obtained safety factor (SF) was 1.907. In the condition of the upper structure load was not working, the obtained safety factor (SF) was 1.045 and during earthquake conditions, the obtained safety factor (SF) was 1.419. While the results of the calculation of the stability of the abutments to overturning failure, when the abutments were in normal conditions, the obtained safety factor (SF) was 4.640. In the condition of the upper structure load was not working, the obtained safety factor (SF) was 1.658 and during earthquake conditions, the obtained safety factor (SF) was 3.159. Because the obtained safety factor (SF) values were greater than 1, the stability of the abutment to sliding failure and overturning failure are considered to be safe.
\end{abstract}

Keywords: Bridge abutment; overturning failure; sliding failure; substructure

\section{Introduction}

Indonesia is one of the developing countries which is currently aggressively carrying out development in all fields. One of these is the development in the field of public works infrastructure. One of the public infrastructures that gets more attention from the government is the development of transportation infrastructures, such as roads and bridges. Road and bridge infrastructure as one of the transportation infrastructure has a very vital role which is directly as a liaison to facilitate transportation between two or more regions [1]. In addition, indirectly, the construction of road and bridge infrastructure can increase the economic growth of a region.

Along with its development, bridge structures have progressed very rapidly, starting with bridges with short spans to long-span bridges that connect between islands and countries [2]. To answer the challenge, a civil engineer must

\footnotetext{
${ }^{*}$ Corresponding author. Tel.: +62-811-4212-748

Jalan TPA Imam Bonjol Atas Air Merah, Kelurahan Wagom

Fakfak, Papua Barat, Indonesia, 98611
}

be involved in adjusting to all the available progress, so that knowledge of the structure of the bridge is sufficiently good and sufficient to anticipate the possibilities that will arise [3].

Every bridge that is built must have a high level of security and comfort for the users so that it can avoid unwanted events. A common problem that is often encountered in bridge construction is the occurrence of structural failures, especially at the bottom of the bridge structure such as the existence of cracks or damage to the abutment of the bridge caused by overloading experienced by the foundation, the occurrence of a large decrease in the bridge foundation which over time can result in structural failure [4].

The bridge structure is composed of elements that are the upper structure, substructure, and complementary bridge structures [5]. The substructure is a component located under the upper structure, which functions to channel all the forces and loads that work on the upper building to the ground. The substructure of a bridge consists of abutments and foundations [6]. 
The substructure of the bridge, which is the abutment structure is used as a retaining wall and to forward the force to the foundation and must be able to provide stability to the influence of external and internal forces [7]. Therefore, in planning abutments, the stability of the construction must be reviewed against the influence of external forces, which can cause overturning failure, sliding failure, and bearing capacity failure, as well as internal forces that can cause construction failure. The stability of the bridge abutment construction must meet the value of the safety factor (SF) so that it can meet the service criteria of a bridge.

\section{Literature Review}

\subsection{Abutment structure}

Abutment is the component of buildings on the upper part of the bridge and also used as a retaining wall. The abutments are adjusted based on the results of land investigations, and as far as possible, they should be placed on hard land so that the tension of the bearing capacity allowable.

By calculating the risk of erosion, the abutment base at least must be $2 \mathrm{~m}$ below the original land surface, especially for abutments with a direct foundation. The function of this abutment is as a bridge beam placement, as a stepping plate placement, as a successor to forces acting on the upper structure to the foundation, as a barrier to active soil pressure. Abutment consists of several types, namely [8] :

- Abutment gravity type

These abutments gain strength and resistance to forces that work by using their weight. Gravity type abutments are often used in structures that are not too high and have good foundation soil. In general, the material used is a pair of river stones or mashed concrete. Usually, gravity type abutments are used on bridges that have a not too long span.

- Abutment reverse T type

This abutment is a retaining wall with cantilever beams composed of an elongated wall and as a strength plate from the wall. The durability of the force acting is obtained from its own weight and the weight of the ground above the support plate/heel. The difference in reverse $\mathrm{T}$ type abutments is slimmer than gravity type abutments.

In general, reverse $\mathrm{T}$ type abutments are used when the abutment height ranges from 6-12 $\mathrm{m}$. This inverted T type abutment can be carried by a pile foundation, or a caisson or even directly dependent foundation, on soil conditions under the abutment.

- Abutment support type

This type of abutment is almost similar to the inverted T type abutment, but this type of abutment is supported on the backside (counterfort), which aims to reduce the force acting on the longitudinal wall and the support. Generally, a support type abutment is used in high structural conditions and using reinforced concrete.

\subsection{Abutment forces}

The forces acting on the abutment are taken from [2].

- Forces due to dead load

In determining the amount of the dead load, the weight of the building materials below must be used [8].

- Cast steel $=7.85 \mathrm{t} / \mathrm{m}^{3}$

- Cast iron $\quad=7.25 \mathrm{t} / \mathrm{m}^{3}$

- Aluminum alloy $\quad=2.80 \mathrm{t} / \mathrm{m}^{3}$

- Reinforced concrete $\quad=2.50 \mathrm{t} / \mathrm{m}^{3}$

- Ordinary concrete, cyclops $=2.20 \mathrm{t} / \mathrm{m}^{3}$

- Stone pair / brick $\quad=2.00 \mathrm{t} / \mathrm{m}^{3}$

- Wood $=1.00 \mathrm{t} / \mathrm{m}^{3}$

- Soil, sand, gravel $\quad=2.00 \mathrm{t} / \mathrm{m}^{3}$

- Asphalt pavement $\quad=2.50 \mathrm{t} / \mathrm{m}^{3}$

- Water $\quad=1.00 \mathrm{t} / \mathrm{m}^{3}$

- Live load

- "T" load

" $\mathrm{T}$ " load is a load which is a truck vehicle that has a double wheel load of 10 tons with sizes and positions as shown in Fig. 1 [2].

- "D" load

a) D" load or line load is the load arrangement in each traffic lane consisting of an equally divided load of "q" tons per meter length per lane, and the load line "P" ton per lane [2]. "D" load as shown in Fig. 2. The size of "q" is determined as follows: $\mathrm{q}=2.2 \mathrm{t} / \mathrm{m} \quad=$ for $\mathrm{L}<30 \mathrm{~m}$ $\mathrm{q}=2.2 \mathrm{t} / \mathrm{m}-1,1 / 60 x(\mathrm{~L}-30) \mathrm{t} / \mathrm{m}=30 \mathrm{~m}<\mathrm{L}<60 \mathrm{~m}$ $\mathrm{q}=1.1(1+30 / \mathrm{L}) \mathrm{t} / \mathrm{m} \quad=$ for $\mathrm{L}>60 \mathrm{~m}$
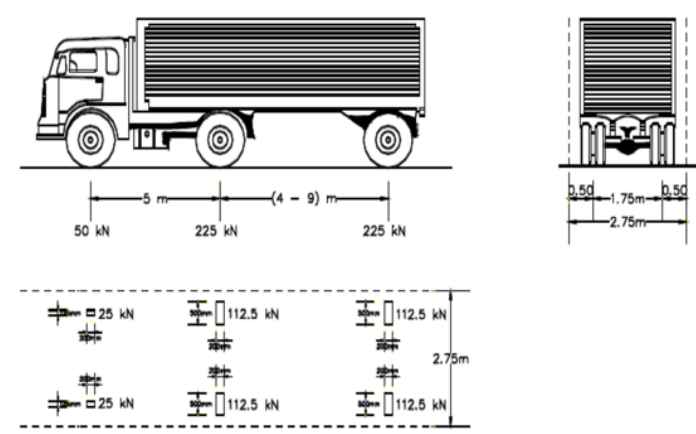

Figure 1. "T" load



Figure 2. "D" load 


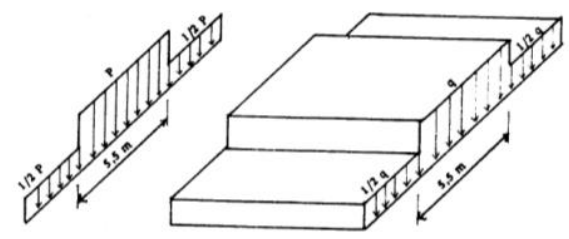

Figure 3. Terms use of "D" load

b) Provisions for using the "D" load in the transverse direction of the bridge are as follows [2]:

(1) For bridges with a vehicle floor width equal to or smaller than 5.50 meters, the full " $\mathrm{D}$ " load $(100 \%)$ must be charged to the entire bridge.

(2) For bridges with a vehicle floor width greater than 5.50 meters, the full " $\mathrm{D}$ " load (100\%) is charged to the 5.50 meters track width while the remaining width is loaded with only half the "D" load (50\%), see Fig. 3.

(3) In determining live loads (evenly divided loads and line loads) it is necessary to note that provision

- Spread length (L) for evenly divided loads is in accordance with the provisions in the formulation of the shock coefficient.

- The live load per meter of bridge width is

$$
\begin{aligned}
& R q L=\frac{q(\text { ton } / m)}{2.75} \times l \\
& R P L=\frac{P(\text { ton })}{2.75} \times k \times l
\end{aligned}
$$

c) Loads on sidewalks, kreb, and backs

(1) Construction of sidewalks must be calculated against live loads of $500 \mathrm{~kg} / \mathrm{m}^{2}$. In calculating the strength of the girder due to the effect of the live load on the sidewalk, a load of $60 \%$ of the sidewalk live load is taken into account.

(2) Kreb which is found on the floor edges of a vehicle must be calculated to be able to withstand a horizontal load across the bridge of $500 \mathrm{~kg} / \mathrm{m}$ which works on the crest peak in question or at a height of $25 \mathrm{~cm}$ above the floor level of the vehicle.

(3) The back pile on each edge of the sidewalk must be calculated to be able to withstand a horizontal load of $100 \mathrm{~kg} / \mathrm{m}$, which works at $90 \mathrm{~cm}$ above the sidewalk floor.

- Wind load

The wind load is distributed evenly on the side plane of each structural element that forms a curved portal in the transverse direction of the bridge. The largest vertical contact area for each side frame element of the bridge structure is taken.

- The wind that blew the side of the bridge

The force due to the wind that blows the side bridge of the bridge is calculated by

$$
T e w 1=0.0006 \times C w \times(V w)^{2} \times A b
$$

- The wind that blew the vehicle

Horizontal wind force on the floor surface of the bridge due to wind loads is calculated using the following formula:

$$
T e w 2=0.0012 \times C w \times(V w)^{2} \times \frac{L}{2}
$$

- Shock load

To take into account the effects of vibrations and other dynamic influences, the stresses due to the load line "P" must be multiplied by the shock coefficient which will give the maximum yield, while the evenly distributed "q" and load "T" are not multiplied by the shock coefficient. The shock coefficient is determined by :

$$
K=\frac{1+20}{(50+L)}
$$

where,

$$
\begin{aligned}
& \mathrm{K}=\text { shock coefficient } \\
& \mathrm{L}=\text { span length }(\mathrm{m})
\end{aligned}
$$

- Forces due to soil pressure

The load of the vehicle behind the retaining wall of the ground is calculated to be as high as $60 \mathrm{~cm}$.

- Brake force and traction

The effect of forces in the longitudinal direction is calculated with the effect of the brake force of $5 \%$ of the load "D" without a shock coefficient that meets all existing traffic lanes and in one direction. The brake force is considered to work horizontally in the direction of the bridge axis with a catch point of 1.80 meters above the floor level of the vehicle.

$$
\text { Traction } R r t=\frac{5 \% \times(R P L+R q L)}{2}
$$

where,

Rrt $=$ forces due to brakes and traction

RPL = line load

$\mathrm{RqL}=$ uniformly distributed load

- Earthquake load due to the upper structure

where,

$$
G 1=K \cdot R v d
$$

$$
\begin{aligned}
K & =0.07 \\
R v d & =\text { vertical force due to dead load }
\end{aligned}
$$

- The force due to friction on the pedestal moves

The friction that arises is only reviewed due to the dead load, while the amount is determined based on the coefficient of friction on the support concerned with the following values:

- Between steel with a mixture of hard copper \& steel......0.5

- Between steel and steel or cast iron.......0.25

- Between rubber and steel/concrete......0.15-0.18 
- Mashed force

To calculate the force due to collisions between vehicles and pillars can be used one of the two most decisive horizontal mash forces:

- In the direction of traffic $=100$ ton

- In the direction of perpendicular traffic $=50$ ton

\subsection{Abutment planning criteria}

In planning the bridge abutment many forces and loads will be taken into account in the abutment [7]. These forces can be seen in Fig. 4.

\subsection{Calculation of abutment stability}

The stability analysis of the bridge abutments is calculated as follows [5] :

- Stability for overturning

Safety factor (FS) is used to ensure the safety of an abutments structure against overturning.

$$
S=\frac{\sum M x}{\sum M y} \geq 1
$$

where,

$\Sigma \mathrm{M}_{\mathrm{x}}=$ total retaining moment

$\Sigma \mathrm{M}_{\mathrm{y}}=$ total overturning moment

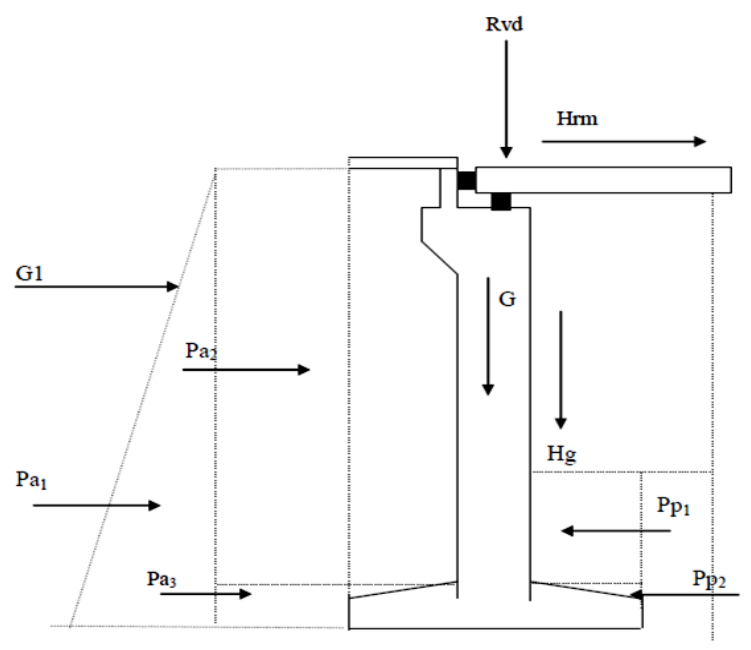

Figure 4. The forces acting on the abutment

Remarks,

$$
\begin{array}{ll}
\mathrm{P}_{\mathrm{a} 1}, \mathrm{P}_{\mathrm{a} 2}, \mathrm{P}_{\mathrm{a} 3}= & \text { the active earth pressure behind at he } \\
& \text { abutment } \\
& \begin{array}{ll}
\text { the passive earth pressure at the front of } \\
\mathrm{P}_{\mathrm{p} 1}, \mathrm{P}_{\mathrm{p} 2}
\end{array} \\
& \text { the abutment } \\
\mathrm{G} & =\text { self-weight abutment } \\
\mathrm{G}_{1} & =\text { earthquake due to the upper building } \\
\mathrm{H}_{\mathrm{g}} & =\text { friction due to moving support } \\
\mathrm{H}_{\mathrm{rm}} & =\text { forces due to brakes } \\
\mathrm{R}_{\mathrm{vd}} & =\text { press force due to load from above }
\end{array}
$$

- Stability for sliding

Safety factor (SF) used to ensure the safety of the structure against the sliding

$$
S F=\frac{\sum V \cdot \tan \frac{2}{3} \phi^{\circ}+c \cdot B}{\sum H} \geq 1
$$

where,

$\Sigma \mathrm{V}=$ total force that holds backsliding

$\Sigma \mathrm{H}=$ total force that causes the sliding

\section{Research Methodology}

\subsection{Time and place of research}

This research was carried out on the Aifa bridge construction project located in Tanibar Village, Fafurwar District, Bintuni Bay Regency, West Papua Province.

\subsection{Detail engineering design and technical data}

Detail engineering design and technical data Aifa bridge obtained from the Ministry of Public Works of the Directorate General of Highways BPJN XVII Manokwari Satker West Papua Province. Detail engineering design which obtained drawing layout, the long section and crosssection of the bridge can be seen in the Figs. 5 and 6 . While technical data of Aifa bridge are among others:
- Bridge type
$=$ concrete reinforcement
- Bridge width
$=10$ meter
- Length of the bridge
$=30$ meter
- Number of main girder
$=6$ pieces
- Distance between girder
$=1.6$ meter
- Bridge height
$=5.146$ meter

\subsection{Research flow chart}

The research is conducted by following a research flow chart shown in Fig. 7

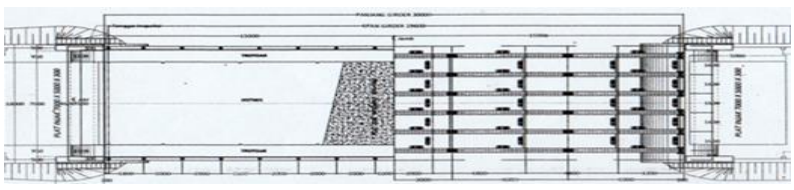

Figure 5. Layout Aifa bridge

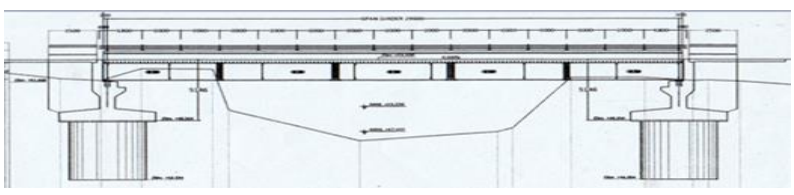

Figure 6. Long section Aifa bridge 


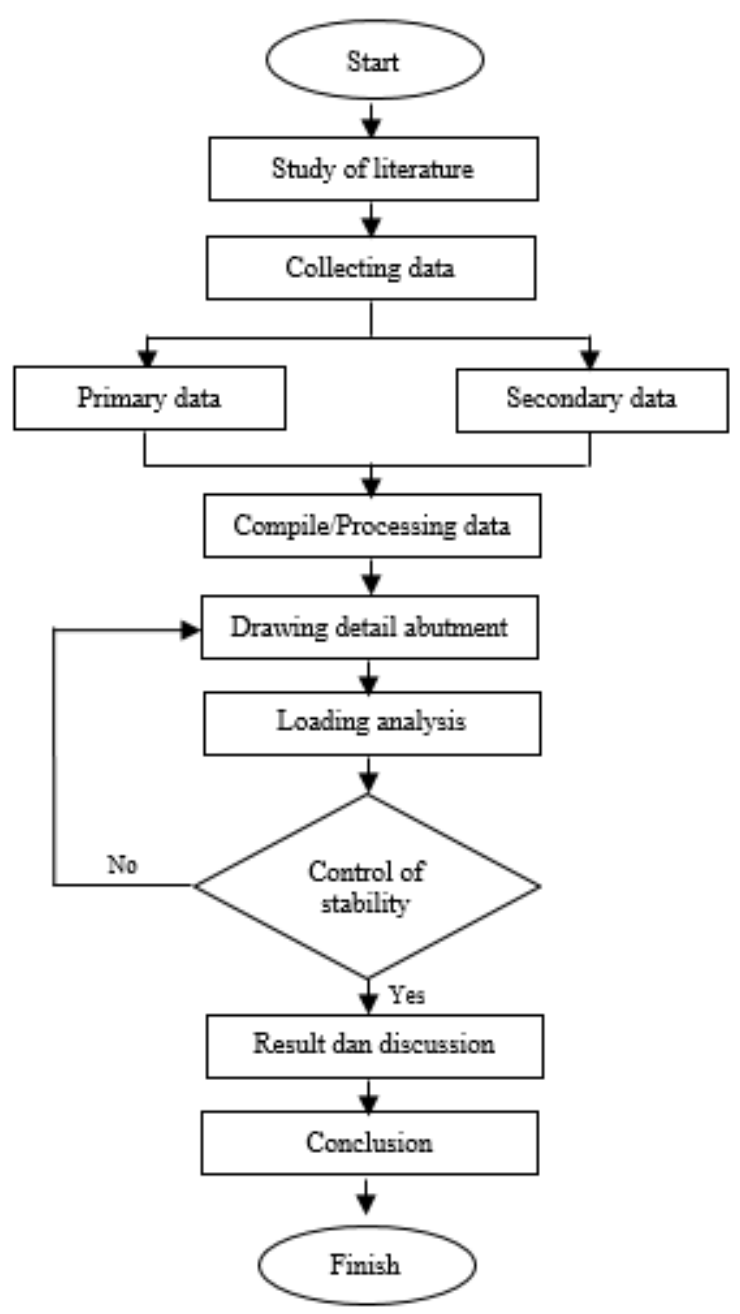

Figure 7. Flow chart of the reserach methodology

\section{Results and Discussion}

\subsection{Overview of abutment dimensions}

- Abutmen drawing detail point 1

From detail engineering design and technical data of Aifa bridge, the abutment detail can be drawn as shown in Fig. 8 .

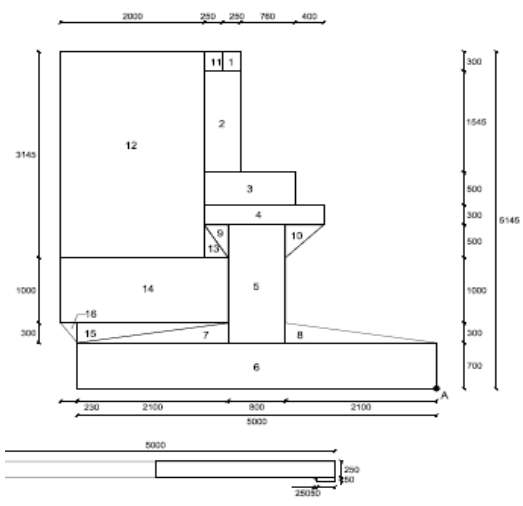

Figure 8. Detail abutment
Table 1. Calculation of dead load

\begin{tabular}{|c|c|c|c|c|c|}
\hline Dead load & $\begin{array}{l}\text { Height } \\
\text { (m) }\end{array}$ & $\begin{array}{c}\text { Width } \\
\text { (m) }\end{array}$ & $\begin{array}{c}\text { Length } \\
\text { (m) }\end{array}$ & $\begin{array}{c}\text { Weight } \\
\text { Vol } \\
\left(\mathbf{t} / \mathbf{m}^{3}\right)\end{array}$ & $\Sigma(t)$ \\
\hline Vehicle floor & 0.2 & 10 & 30 & 2.5 & 150 \\
\hline $\begin{array}{l}\text { Rainwater (3 } \\
\mathrm{cm})\end{array}$ & 0.03 & 10 & 30 & 1 & 9 \\
\hline Asphalt $(7 \mathrm{~cm})$ & 0.07 & 10 & 30 & 2.2 & 46.2 \\
\hline Sidewalk & 0.2 & 10 & 30 & 2.5 & 30 \\
\hline Backrest pipe & 4 & 0.00091 & 30 & 7.25 & 0.7804 \\
\hline Backrest pile & 0.1 & 0,15 & 1 & 2.5 & 0.3 \\
\hline $\begin{array}{l}\text { Main girder } \\
\text { IWF } \\
\text { 900.300.28.16 } \\
\text { Unexpected } \\
\text { Load }\end{array}$ & 1.845 & 0.4 & 30 & 7.85 & 1390.39 \\
\hline & & & & $\mathbf{P}_{\text {total }}=$ & 1631.68 \\
\hline
\end{tabular}

- Loading analysis

- Dead load

For the calculation of dead loads that work on abutments can be seen in Table 1 .

$$
R v D=\frac{\text { Ptotal }}{2}=\frac{1631,68}{2}=815,841 \text { ton }
$$

- Live load

Live load $\mathrm{LL}=12$ ton, $\mathrm{qL}=2.2 \mathrm{t} / \mathrm{m}$ (from PPJJR article 1).

Traffic width $=7 \mathrm{~m}$

$$
\begin{aligned}
R q L & =\frac{q}{2.75} \times l=\frac{2.2}{2.75} \times 7 \\
& =5.6 \text { ton } \\
R P L & =\frac{P}{2.75} \times k \times l=\frac{12}{2.75} \times 1250 \times 7 \\
& =38.182 \mathrm{ton}
\end{aligned}
$$

- Shock coefficient (k)

$$
\begin{aligned}
K & =1+\frac{20}{50+L}=1+\frac{20}{50+30} \\
& =1.250 \text { ton } \\
R v L & =(k \times R P L)+\left(\frac{1}{2} \times R q L\right) \\
& =(1.250 \times 38.182)+\left(\frac{1}{2} \times 5.6\right) \\
& =50.527 \text { ton }
\end{aligned}
$$

- Forces due to brakes and traction

Calculated 5\% of load D without a shock coefficient with a catch point $1.8 \mathrm{~m}$ above the vehicle floor Surface. 


$$
\begin{aligned}
R r t & =\frac{5 \% \times(R P L+R q L)}{2} \\
& =\frac{5 \% \times(36.099+5.6)}{2}=1.095 \text { ton }
\end{aligned}
$$

- Friction force on the moving pedestal Price of motion coefficient taken 0.25 from PPPGJR article 2.6.2.

$$
\begin{aligned}
G g & =\text { coefficien to friction } \times R v D \\
& =0.25 \times 815.841=203.960 \text { ton } \quad(16)
\end{aligned}
$$

- Earthquake forces

$$
\begin{aligned}
E l & =K \times R v D \\
& =0.07 \times 815.541=57.109 \text { ton }
\end{aligned}
$$

- Analysis of abutment appearance and earth pressure a) Cross-section abutment

Based on the area of the abutment reviewed, the weight for the abutment body was obtained as shown in Table 2.

$$
\begin{aligned}
X c & =\frac{\sum M x}{\sum A c} \\
& =\frac{19.779}{7.761}=2.549 \mathrm{~m} \\
Y c & =\frac{\sum M y}{\sum A c} \\
& =\frac{11.299}{7.761}=1.456 \mathrm{~m}
\end{aligned}
$$

b) Earth in front of and behind the abutment Based on the area of earth beside the abutment, we obtain data on the center of gravity for the earth behind the abutment as shown in Table 3 . From Table 3 obtained the distance from the center of weight to point $\mathrm{Z}$ is

$$
\begin{aligned}
X c & =\frac{\sum M x}{\sum A c} \\
& =\frac{54.069}{10.407}=4.331 \mathrm{~m} \\
Y c & =\frac{\sum M y}{\sum A c} \\
& =\frac{33.255}{10.407}=3.196 \mathrm{~m}
\end{aligned}
$$

\begin{tabular}{|c|c|c|c|c|c|c|c|c|}
\hline \multirow[t]{2}{*}{ No. } & \multicolumn{2}{|c|}{$\begin{array}{l}\text { Calculation of } \\
\text { Abutment Load }\end{array}$} & \multirow{2}{*}{$\begin{array}{c}\text { Cross Section } \\
\left(\mathbf{m}^{2}\right)\end{array}$} & \multirow{2}{*}{$\begin{array}{l}\text { Spesific } \\
\text { Gravity } \\
\left(\text { ton } / \mathbf{m}^{3}\right)\end{array}$} & \multicolumn{2}{|c|}{ Arm from $Z$} & \multirow{2}{*}{$\begin{array}{l}\text { Mx }= \\
\text { Ac.X }\end{array}$} & \multirow{2}{*}{$\begin{array}{l}\text { My = } \\
\text { Ac.Y }\end{array}$} \\
\hline & $\mathbf{P}(\mathbf{m})$ & $\mathbf{L}(\mathbf{m})$ & & & $\mathbf{X}(\mathbf{m})$ & $\mathrm{Y}(\mathrm{m})$ & & \\
\hline 1 & 0.3 & 0.25 & 0.075 & 2.5 & 2.855 & 4.996 & 0.214 & 0.375 \\
\hline 2 & 1.546 & 0.5 & 0.773 & 2.5 & 2.980 & 4.073 & 2.304 & 3.148 \\
\hline 3 & 0.5 & 1.26 & 0.630 & 2.5 & 2.600 & 3.050 & 1.638 & 1.922 \\
\hline 4 & 0.3 & 1.66 & 0.498 & 2.5 & 2.400 & 2.650 & 1.195 & 1.320 \\
\hline 5 & 1.8 & 0.8 & 1.440 & 2.5 & 2.500 & 1.600 & 3.600 & 2.304 \\
\hline \multirow[t]{2}{*}{6} & 0.7 & 5.0 & 3.500 & 2.5 & 2.500 & 0.350 & 8.750 & 1.225 \\
\hline & $\mathbf{T}(\mathbf{m})$ & $\mathbf{A}(\mathbf{m})$ & & & & & & \\
\hline 7 & 0.3 & 2.1 & 0.315 & 2.5 & 3.600 & 0.800 & 1.134 & 0.252 \\
\hline 8 & 0.3 & 2.1 & 0.315 & 2.5 & 1.400 & 0.800 & 0.441 & 0.252 \\
\hline 9 & 0.33 & 0.5 & 0.083 & 2.5 & 3.010 & 2.333 & 0.248 & 0.192 \\
\hline \multirow[t]{2}{*}{10} & 0.5 & 0.53 & 0.133 & 2.5 & 1.923 & 2.333 & 0.255 & 0.309 \\
\hline & & Total $=$ & 7.761 & & & & 9.779 & 1.299 \\
\hline
\end{tabular}

c) Earth pressure

From the results of soil testing at the Soil Testing Laboratory Polytechnic State of Fakfak obtained soil characteristic as follows :

$\begin{array}{ll}\text { Angle friction internal }(\phi) & =19.60^{\circ} \\ \text { Cohesion }(\mathrm{c}) & =7.133 \\ \text { Weight volume soil }(\gamma) & =1.1 \mathrm{t} / \mathrm{m}^{3} \\ \text { Soil depth }\left(\mathrm{h}_{1}\right) & =5.146 \mathrm{~m} \\ \text { Soil depth }\left(\mathrm{h}_{2}\right) & =1.200 \mathrm{~m}\end{array}$

(a) Calculation of coefficient of active earth pressure

$$
\begin{aligned}
K a & =\operatorname{tg}^{2}\left(45^{\circ}-\frac{\phi}{2}\right) \\
& =\operatorname{tg}^{2}\left(45^{\circ}-\frac{19.60^{\circ}}{2}\right) \\
& =0.751
\end{aligned}
$$

Table 2. Calculation of abutment own weight 
Table 3. Calculation of soil weight behind abutment

\begin{tabular}{|c|c|c|c|c|c|c|c|c|}
\hline \multirow{2}{*}{ No. } & \multicolumn{2}{|c|}{$\begin{array}{c}\text { Calculation of } \\
\text { Abutment Load }\end{array}$} & \multirow{2}{*}{$\begin{array}{c}\text { Cross Section } \\
\left(\mathbf{m}^{2}\right)\end{array}$} & \multirow{2}{*}{$\begin{array}{l}\text { Spesific } \\
\text { Gravity } \\
\left(\text { ton/m } / \mathbf{m}^{3}\right)\end{array}$} & \multicolumn{2}{|c|}{ Arm from $Z$} & \multirow{2}{*}{$\begin{array}{l}\text { Mx }= \\
\text { Ac.X }\end{array}$} & \multirow{2}{*}{$\begin{array}{l}\text { My = } \\
\text { Ac.Y }\end{array}$} \\
\hline & $\mathbf{P}(\mathbf{m})$ & $\mathbf{L}(\mathrm{m})$ & & & $\mathbf{X}(\mathbf{m})$ & $\mathbf{Y}(\mathbf{m})$ & & \\
\hline 11 & 0.30 & 0.25 & 0.075 & 2.5 & 3.105 & 4.996 & 0.233 & 0.375 \\
\hline 12 & 3.146 & 2.000 & 6.292 & 2.5 & 4.230 & 3.573 & 26.615 & 22.481 \\
\hline \multirow[t]{2}{*}{13} & 1.00 & 2.33 & 2.330 & 2.5 & 4.065 & 1.500 & 9.471 & 3.495 \\
\hline & $\mathrm{T}$ & $\mathrm{A}$ & & & & & & \\
\hline 14 & 0.330 & 0.500 & 0.083 & 2.5 & 3.120 & 2.167 & 0.257 & 0.179 \\
\hline 15 & 0.300 & 2.100 & 0.315 & 2.5 & 4.300 & 0.900 & 1.355 & 0.284 \\
\hline \multirow[t]{3}{*}{16} & 0.230 & 0.300 & 0.035 & 2.5 & 5.077 & 0.900 & 0.175 & 0.031 \\
\hline & & Total $=$ & 9.1290 & & & & 38.107 & 26.844 \\
\hline & $\mathbf{P}(\mathbf{m})$ & $\mathbf{L}(\mathbf{m})$ & & & & & & \\
\hline 17 & 0.25 & 5.00 & 1.250 & 2.5 & 5.450 & 5.021 & 6.813 & 6.276 \\
\hline 18 & 0.05 & 0.25 & 0.013 & 2.5 & 7.825 & 4.871 & 0.098 & 0.061 \\
\hline \multirow[t]{2}{*}{19} & 0.05 & 0.25 & 0.013 & 2.5 & 3.075 & 4.871 & 0.038 & 0.061 \\
\hline & $\mathbf{T}(\mathbf{m})$ & $\mathbf{A}(\mathbf{m})$ & & & & & & \\
\hline 19 & 0.05 & 0.05 & 0.001 & 2.5 & 3.216 & 4.879 & 0.004 & 0.006 \\
\hline \multirow[t]{2}{*}{20} & 0.05 & 0.05 & 0.001 & 2.5 & 7.683 & 4.879 & 0.010 & 0.006 \\
\hline & & Total $=$ & 1.2775 & & & & 6.9624 & 6.4102 \\
\hline
\end{tabular}

Table 4. Calculation of soil weight front abutment

\begin{tabular}{|c|c|c|c|c|c|c|c|c|}
\hline \multirow{2}{*}{ No } & \multicolumn{2}{|c|}{$\begin{array}{c}\text { Calculation of } \\
\text { Abutment Load }\end{array}$} & \multirow{2}{*}{$\begin{array}{l}\text { Cross Section } \\
\left(\mathbf{m}^{2}\right)\end{array}$} & \multirow{2}{*}{$\begin{array}{l}\text { Spesific } \\
\text { Gravity } \\
\left(\text { ton } / \mathbf{m}^{\mathbf{3}}\right)\end{array}$} & \multicolumn{2}{|c|}{$\operatorname{Arm}$ from $Z$} & \multirow{2}{*}{$\begin{array}{l}\text { Mx }= \\
\text { Ac } . \mathbf{x}\end{array}$} & \multirow{2}{*}{$\begin{array}{c}\text { My }=\mathbf{A c} \\
\cdot \mathbf{y}\end{array}$} \\
\hline & $\mathbf{P}(\mathbf{m})$ & $\mathbf{L}(\mathbf{m})$ & & & $\mathbf{X}(\mathbf{m})$ & $\mathbf{Y}(\mathbf{m})$ & & \\
\hline \multirow[t]{2}{*}{21} & 0.300 & 1.800 & 0.270 & 2.5 & 0.600 & 0.900 & 0.162 & 0.243 \\
\hline & Tota & & 0.270 & & & & 0.162 & 0.243 \\
\hline
\end{tabular}

Table 5. External forces when normal conditions

\begin{tabular}{|c|c|c|c|c|c|c|}
\hline \multirow[b]{2}{*}{ Forces } & \multirow[b]{2}{*}{ V (ton) } & \multirow[b]{2}{*}{ H (ton) } & \multicolumn{2}{|c|}{ Moment Arm } & \multirow{2}{*}{$\begin{array}{c}\text { Mx }=V \cdot x \\
\text { Retaining } \\
\text { Moment } \\
(t m)\end{array}$} & \multirow{2}{*}{$\begin{array}{c}\text { My }=\mathbf{H} \cdot \mathbf{y} \\
\text { Overtuning } \\
\text { Moment } \\
(\mathrm{tm})\end{array}$} \\
\hline & & & $\mathbf{X}(\mathbf{m})$ & $\mathbf{Y}(\mathbf{m})$ & & \\
\hline $\mathrm{R}_{\mathrm{v}}$ & 859.623 & & 2.500 & & 2149.058 & \\
\hline $\mathrm{W}_{\mathrm{c}}$ & 194.025 & & 2.549 & & 494.476 & \\
\hline $\mathrm{W}_{\mathrm{td}}$ & 2.959 & & 0.600 & & 1.776 & \\
\hline $\mathrm{W}_{\mathrm{tb}}$ & 114.055 & & 4.331 & & 493.955 & \\
\hline $\mathrm{R}_{\mathrm{rt}}$ & & 1.000 & & 5.450 & & 5.450 \\
\hline $\mathrm{G}_{\mathrm{g}}$ & & 10.568 & & 7.000 & & 73.973 \\
\hline $\mathrm{P}_{\mathrm{a} 1}$ & & 84.979 & & 3.196 & & 271.554 \\
\hline \multirow[t]{2}{*}{$\mathrm{P}_{\mathrm{a} 2}$} & & 108.927 & & 1.598 & & 174.042 \\
\hline & & $I=205$. & & & & \\
\hline $\mathrm{P}_{\mathrm{p}}$ & & 19.187 & & 0.600 & & 11.512 \\
\hline $\mathrm{T}_{\mathrm{b}}$ & & 50.000 & & 2.800 & & 140.000 \\
\hline & $=1170$. & & & & 3139.264 & 676.530 \\
\hline
\end{tabular}


Table 6. External forces when the upper structure load is not working

\begin{tabular}{|c|c|c|c|c|c|c|}
\hline \multirow[b]{2}{*}{ Forces } & \multirow[b]{2}{*}{$V($ ton $)$} & \multirow[b]{2}{*}{$\mathbf{H}$ (ton) } & \multicolumn{2}{|c|}{ Moment Arm } & \multirow{2}{*}{$\begin{array}{c}\mathbf{M x}=\mathrm{V} \cdot \mathrm{x} \\
\begin{array}{c}\text { Retaining } \\
\text { Moment } \\
(\mathrm{tm})\end{array}\end{array}$} & \multirow{2}{*}{$\begin{array}{c}\text { My }=H \cdot y \\
\text { Overtuning } \\
\text { Moment } \\
\text { (tm) }\end{array}$} \\
\hline & & & $\mathbf{X}(\mathbf{m})$ & $\mathbf{Y}(\mathbf{m})$ & & \\
\hline $\mathrm{W}_{\mathrm{c}}$ & 194.025 & & 2.549 & & 494.476 & \\
\hline $\mathrm{W}_{\mathrm{td}}$ & 2.959 & & 0.600 & & 1.776 & \\
\hline $\mathrm{W}_{\mathrm{tb}}$ & 114.055 & & 4.331 & & 493.955 & \\
\hline $\mathrm{P}_{\mathrm{a} 1}$ & & 84.979 & & 3.196 & & 271.554 \\
\hline \multirow[t]{2}{*}{$\mathrm{P}_{\mathrm{a} 2}$} & & 108.927 & & 1.598 & & 174.042 \\
\hline & & $\Sigma H=193.906$ & & & & \\
\hline $\mathrm{P}_{\mathrm{p}}$ & & 19.187 & & 0.600 & & 11.512 \\
\hline $\mathrm{T}_{\mathrm{b}}$ & & 50.000 & & 2.800 & & 140.000 \\
\hline$\Sigma$ & $\Sigma V=311.039$ & & & & 990.206 & 597.107 \\
\hline
\end{tabular}

Table 7. External forces during earthquake conditions

\begin{tabular}{|c|c|c|c|c|c|c|}
\hline \multirow[b]{2}{*}{ Forces } & \multirow[b]{2}{*}{ V (ton) } & \multirow[b]{2}{*}{$\mathbf{H}$ (ton) } & \multicolumn{2}{|c|}{ Moment Arm } & \multirow{2}{*}{$\begin{array}{c}M x=V \cdot x \\
\text { Retaining } \\
\text { Moment } \\
(t m)\end{array}$} & \multirow{2}{*}{$\begin{array}{c}\text { My }=\mathbf{H} \cdot \mathbf{y} \\
\begin{array}{c}\text { Overtuning } \\
\text { Moment } \\
(\text { tm) }\end{array}\end{array}$} \\
\hline & & & $\mathbf{X}(\mathbf{m})$ & $\mathbf{Y}(\mathbf{m})$ & & \\
\hline $\mathrm{R}_{\mathrm{v}}$ & 859.623 & & 2.500 & & 2149.058 & \\
\hline $\mathrm{W}_{\mathrm{c}}$ & 194.025 & & 2.549 & & 494.476 & \\
\hline $\mathrm{W}_{\mathrm{td}}$ & 2.959 & & 0.600 & & 1.776 & \\
\hline $\mathrm{W}_{\mathrm{tb}}$ & 114.055 & & 4.331 & & 493.955 & \\
\hline $\mathrm{R}_{\mathrm{rt}}$ & & 1.000 & & 5.450 & & 5.450 \\
\hline $\mathrm{G}_{\mathrm{g}}$ & & 10.568 & & 7.000 & & 73.973 \\
\hline $\mathrm{P}_{\mathrm{a} 1}$ & & 84.979 & & 3.196 & & 271.554 \\
\hline $\mathrm{P}_{\mathrm{a} 2}$ & & 108.927 & & 1.598 & & 174.042 \\
\hline $\mathrm{E}_{1}$ & & 57.109 & & 5.146 & & 293.882 \\
\hline \multirow[t]{2}{*}{$\mathrm{E}_{2}$} & & 13.582 & & 1.715 & & 23.297 \\
\hline & & $\Sigma H=276.164$ & & & & \\
\hline $\mathrm{P}_{\mathrm{p}}$ & & 19.187 & & 0.600 & & 11.512 \\
\hline $\mathrm{T}_{\mathrm{b}}$ & & 50.000 & & 2.800 & & 140.000 \\
\hline
\end{tabular}

(b) Calculation of coefficient of passive earth pressure

$$
\begin{aligned}
K p & =\operatorname{tg}^{2}\left(45^{\circ}-\frac{\phi}{2}\right) \\
& =\operatorname{tg}^{2}\left(45^{\circ}-\frac{19.60^{\circ}}{2}\right) \\
& =1.332
\end{aligned}
$$

(c) Calculation of active earth pressure

$$
\begin{aligned}
P a_{1} & =k_{a} \times q \times h_{1} \times b \\
& =0.751 \times 2.2 \times 5.146 \times 10 \\
& =84.98 \text { ton }
\end{aligned}
$$

$$
\begin{aligned}
P a_{2} & =\frac{1}{2} \times k_{a} \times \gamma \times\left(h_{1}\right)^{2} \times b \\
& =\frac{1}{2} \times 0.751 \times 1.1 \times 26.4814 \times 10 \\
& =108.93 \text { ton }
\end{aligned}
$$

(d) Calculation of passive earth pressure

$$
\begin{aligned}
P p & =\frac{1}{2} \times k_{p} \times \gamma \times\left(h_{2}\right)^{2} \times b \\
& =\frac{1}{2} \times 1.332 \times 1.1 \times 1.44 \times 10 \\
& =19.19 \text { ton }
\end{aligned}
$$


(e) Calculation of abutment stability

- When normal conditions

Based on the calculation results of the reaction on the building under the bridge obtained external forces when normal conditions in Table 5.

a) Stability to the foundation sliding

$$
\begin{aligned}
& \sum V=\text { vertical forces } \\
& =1170.662 \text { ton } \\
& \sum H=\text { horizontal forces } \\
& =205.473 \text { ton } \\
& S F=\frac{\sum V \times \tan \frac{2}{3} \times \phi^{\circ}+c \times B}{\sum H} \\
& =\frac{1170.662 \times 0.012 \times 19.60^{\circ}+13.430 \times 10.000}{205.473} \\
& =1.907 \geq 1 \rightarrow O K
\end{aligned}
$$

b) Stability of the foundation overturning

$$
\begin{gathered}
\sum M x=\text { retaining moment } \\
=3139.264 \text { ton } \\
\begin{aligned}
\sum M y= & \text { overturning moment } \\
& =675.530 \text { ton } \\
S F= & \frac{\sum M x}{\sum M y}=\frac{3139.264}{676.530} \\
= & 4.640 \geq 1 \rightarrow O K
\end{aligned}
\end{gathered}
$$

- When the upper structure load is not working Based on the calculation results of the reaction on the building under the bridge, the obtained external forces when the upper structure load is not working in Table 6.

a) Stability to the foundation sliding

$$
\begin{aligned}
\sum V & =\text { vertical forces } \\
& =311.039 \text { ton } \\
\sum H & =\text { horizontal forces } \\
& =193.906 \text { ton } \\
S F= & \frac{\sum V \times \tan \frac{2}{3} \times \phi^{\circ}+c \times B}{\sum H} \\
= & \frac{311.039 \times 0.012 \times 19.60^{\circ}+13.430 \times 10.000}{193.906} \\
= & 1.045 \geq 1 \rightarrow O K
\end{aligned}
$$

b) Stability of the foundation overturning

$$
\begin{gathered}
\sum \begin{aligned}
\sum M & =\text { retaining moment } \\
& =990.206 \text { ton }
\end{aligned} \\
\begin{aligned}
\sum M y & =\text { overturning moment } \\
& =597.107 \text { ton } \\
S F= & \frac{\sum M x}{\sum M y}=\frac{990.206}{597.107} \\
= & 1.658 \geq 1 \rightarrow O K
\end{aligned}
\end{gathered}
$$

- During earthquake conditions

Based on the calculation results of the reaction on the building under the bridge obtained external forces during earthquake conditions in Table 7.

a) Stability to the foundation sliding

$$
\begin{gathered}
\sum V=\text { vertical forces } \\
=1170.662 \text { ton } \\
\sum H=\text { horizontal forces } \\
=276.164 \text { ton } \\
S F=\frac{\sum V \times \tan \frac{2}{3} \times \phi^{\circ}+c \times B}{\sum H} \\
=\frac{1170.662 \times 0.012 \times 19.60^{\circ}+13.430 \times 10.000}{276.164} \\
=1.419 \geq 1 \rightarrow O K
\end{gathered}
$$

From the results of the analysis carried out above, dimensions of the planned abutment can withstand the loads that work, both loads that work from within such as the weight of the bridge structure, earth pressure from the side and loads that work from outside such as vehicle loads, wind loads and earthquake loads.

\section{Conclusion}

Based on data analysis that has been implemented, the following conclusions can be drawn:

1. From the results of the calculation of the stability of the abutments to sliding failure, when the abutments are in normal conditions was obtained safety factor (SF) values 1.91 , in condition of the the upper structure load is not working was obtained safety factor (SF) values 1.05 and during earthquake conditions was obtained safety factor (SF) values 1.42. Because obtained safety factor (SF) values greater than 1 , so that the stability of the abutment is safe against sliding failure.

2. From the results of the calculation of the stability of the abutments to overturning failure, when the abutments are in normal conditions was obtained safety factor (SF) 
values 4.64 , in condition of the the upper structure load is not working was obtained safety factor (SF) values 1.66 and during earthquake conditions was obtained safety factor (SF) values 3.16. Because obtained safety factor (SF) values greater than 1, so that the stability of the abutment is safe against overturning failure.

\section{Acknowledgment}

The authors wish to acknowledge the Ministry of Research, Technology and Higher Education Republic of Indonesia (RISTEKDIKTI-RI) for providing the funds for this research with scheme Beginner Lecturer Research (PDP) year 2019. The author also thanks to the Ministry of Public Works of the Directorate General of Highways (BPJN XVII Manokwari) for technical data and detail engineering design Aifa bridge.

\section{References}

[1] Anonim, (1996), "Bridge Management System”, Publishers : Public Works Foundation, Jakarta.

[2] Anonim, (1987), "Planning Guidelines for Loading Street Bridges", Publishers : Public Works Foundation, Jakarta. [in Bahasa]

[3] Anonim, (2015), "General Guidelines for Bridge Planning", Publishers : Public Works Ministry, Jakarta. [in Bahasa]

[4] Bowles, J.E., (1996), Foundation Anaysis and Design, McGraw-Hill, New York

[5] Hartanto, Tri. Kurniawan, Achendri M., (2018), "Calculation of Structure and Volume of Concrete Bridge Abutment Buildings (Case Study of Reinforced Concrete Bridges in Jolosutro Blitar Village)", Jurnal Qua Teknika, 8 (1) : 1-10. Fakultas Teknik Universitas Islam Blitar, Blitar. [in Bahasa]

[6] Hidayat, Gawit, (2011), "Study Abutment Damage Bridge Analysis Study in Bahalang River, Central Kalimantan", Jurnal Teknologi Berkelanjutan, Vol. 1 Ed. 1, pp : 9-17. [in Bahasa]

[7] Lapis, J. O. Balamba, S. Sompie, O. B. A. Sarajar, Alva N., (2013), "Bridge Foundation Stability Analysis (Case Study: Essang-Lalue Bridge)”, Jurnal Sipil Statik Vol. 1 No. 11, Fakultas Teknik, Jurusan Teknik Sipil, Universitas Sam Ratulangi Manado. [in Bahasa]

[8] Manu, Agus Iqbal, (1995), "Fundamentals of Planning a Reinforced Concrete Bridge”, Publishers : Public Works Foundation, Jakarta. [in Bahasa] 